\title{
Modelling Chemical Preservation of Plantain Hybrid Fruits
}

\author{
Ogueri Nwaiwu ${ }^{1 *}$, Martin Itumoh ${ }^{2}$ \\ ${ }^{1}$ Alpha Altis, Sir Collin Campbell Building, University of Nottingham Innovation Park, Triumph road, NG7 2TU, United Kingdom \\ ${ }^{2}$ Department of Agribusiness and management, Faculty of Agriculture, Federal University Ndufu Alike Ikwo, Ebonyi 480101, Ebonyi State, Nigeria
}

\begin{tabular}{l} 
A R T I C L E I N F O \\
Research Article \\
Received 01 April 2017 \\
Accepted 05 May 2017 \\
\hline
\end{tabular}

Keywords:

Plantain

Hybrid fruits

Chemical preservatives

Ripening

Weight loss

*Corresponding Author:

E-mail: ogueri.nwaiwu@alpha-altis.co.uk \begin{abstract}
A B S T R A C T
New plantain hybrids plants have been developed but not much has been done on the post-harvest keeping quality of the fruits and how they are affected by microbial colonization. Hence fruits from a tetraploid hybrid PITA 2 (TMPx 548-9) obtained by crossing plantain varieties Obino l'Ewai and Calcutta 4 (AA) and two local triploid (AAB) plantain landraces Agbagba and Obino l'Ewai were subjected to various concentrations of acetic, sorbic and propionic acid to determine the impact of chemical concentration, chemical type and plantain variety on ripening and weight loss of plantain fruits. Analysis of titratable acidity, moisture content and total soluble solids showed that there were no significant differences between fruits of hybrid and local varieties. The longest time to ripening from harvest ( 24 days) was achieved with fruits of Agbagba treated with 3\% propionic acid. However, fruits of PITA 2 hybrid treated with propionic and sorbic acid at $3 \%$ showed the longest green life which indicated that the chemicals may work better at higher concentrations. The Obino l'Ewai cultivar had the highest weight loss for all chemical types used. Modelling data obtained showed that plantain variety had the most significant effect on ripening and indicates that ripening of the fruits may depend on the plantain variety. It appears that weight loss of fruits from the plantain hybrid and local cultivars was not affected by the plantain variety, chemical type. The chemicals at higher concentrations may have an effect on ripening of the fruits and will need further investigation.
\end{abstract}

DOI: https://doi.org/10.24925/turjaf.v5i8.950-956.1256

\section{Introduction}

Plantain (Musa spp. AAB) is believed to have originated from South East Asia and it is known as an important staple food in West and Central Africa, Latin America and Asia (Norgrove and Hauser, 2015). The annual harvest of plantain and banana is approximately 145 million tonnes worldwide and ranks among the 10top staple foods of the developing world (Ortiz and Swennen, 2014). The unripe fruit is usually cooked and eaten by people affected with diabetes (Odenigbo et al., 2013; Famakin et al., 2016) due to its low sugar content. The micronutrients of plantain include potassium, Lascorbic acid, alpha-carotene and beta-carotene (Avallone et al., 2009). Plantain fruits can be eaten in a variety of ways and the proximate composition may be affected by ripening and cooking (Baiyeri et al., 2011).

Plantains can be affected by bunchy top virus (Adegbola et al., 2013) and a number of diseases and pests primarily black sigatoka caused by Mycosphaerella fijiensis, Fusarium wilt, nematodes and weevils (Orluchukwu and Ogburia, 2014). To mitigate the devastating effects of these diseases new plantain hybrids which are resistant have been developed through different breeding programs around the world. These programs aim at achieving high yield and quality (Ortiz et al., 1997) and may also incorporate genetic engineering and genomicsled breeding to enhance their effectiveness (Ortiz, 2013). The plant breeding programs also aim to give farmers improved varieties that are superior to the local cultivars. Tremendous progress has been made in plantain breeding which has led to the cultivation of new plantain hybrids that produced fruits that are superior to some plantain landraces in nutritional value (Adeniji et al., 2007). The breeding programs and projects have proved to impact positively on the enterprise of farmers and have resulted in increased plantain production (Faturoti et al., 2009). The level of progress made so far in breeding has not been replicated in the post-harvest storage of the fruit and more work needs to be done to reduce post-harvest losses caused by microbial colonization of the fruits after ripening. According to Ogundare-Akanmu et al. (2015), post-harvest loss is a major problem limiting the production of plantain. The available data on current production of the crops suggest that Nigeria could have been a leading exporter of plantain fruits if not for postharvest losses (Adeniyi and Ayandiji, 2014). It has been pointed out that losses of fruit after harvest are 
typically less than $10 \%$ and the distance between production areas and the major markets affects the short storage life of the crop under tropical conditions (Aked et al., 2000). In recent years, farmers and plantain processors have adopted a variety of ways to reduce post-harvest losses. This includes processing of plantain into flours or snack foods like plantain chips. Passive modified packaging of the fruits with low density polyethylene sheets (Nwaiwu et al., 2003) and treating of fruits in chemicals like Semperfresh ${ }^{\mathrm{TM}}$ has been suggested (Yurdugül, 2016). The use of edible coating is now widespread and is believed to be an environmentally friendly technology that offers substantial advantages for shelf-life increase of many food products including fruits and vegetables (Valencia-Chamorro et al., 2011). According to Moreira et al. (2011), coatings obtained from generally recognized as safe (GRAS) materials, have the potential to reduce weight loss, respiration rate, and improve food appearance and integrity. Furthermore, chemical treatment in particular can reduce enzymatic browning (Mahajan et al., 2014) and can be used in combination with other food preservation techniques in order to extend the effectiveness of the food preservation chain. Also the chemicals can reduce, inhibit, or delay the growth of microorganisms on the surface of food they are in contact with. However, it has been explained that the success of edible coatings for fresh products totally depends on the control of internal gas composition and that quality criteria for fruits and vegetables coated with edible films must be determined carefully throughout the storage period (Dhall, 2013).

From literature, new plantain hybrid fruits have not been tested exhaustively to determine how they will keep in common post-harvest storage conditions. Therefore, the aim of this study was to model and determine the significance or impact of chemical concentration, chemical type and plantain variety on ripening and weight loss of plantain hybrid fruits after chemical treatment.

\section{Materials and Methods}

\section{Experimental Design and Plantain Fruit Samples}

Plantain accessions grown at the International Institute of Tropical Agriculture (IITA), High Rainfall Station, Onne, Nigeria, were used for the study. The matured green fruits from a tetraploid hybrid PITA 2 (TMPx 5489) obtained by crossing plantain varieties Obino l'Ewai and Calcutta 4 (AA) were studied. Two local triploid (AAB) plantain landraces Agbagba and Obino l'Ewai were also assessed for comparison. Plantain fruits were obtained from field plots that were used for other studies of post-harvest physical attributes of plantain fruit bunches. The design of this study was essentially a random analytical observational study, because plantain fruit bunches were chosen at random after harvest. Treated and untreated fruits were monitored physically after which changes were recorded. Plantain bunches were de-handed within one hour after harvest and then separated from the hands, washed and air dried for $1 \mathrm{~h}$. Three fruits in three replicates from 3 batches were analysed for each parameter.

\section{Chemical Treatment of Plantain Fruits}

Three chemical preservatives were used namely acetic acid, propionic acid and sorbic acid (Sigma- Aldrich, Dorset, United Kingdom) and were prepared with distilled water. Acetic acid and propionic acid were prepared at different concentrations $(1,2$, and $3 \% \mathrm{v} / \mathrm{v})$ after which sorbic acid was prepared $(1,2$, and $3 \% \mathrm{w} / \mathrm{v})$. Plantain fruits harvested as described above were separated into single fruits before preparing water solutions as described by Yurdugül (2016) with modification. Instead of dipping fruits into a coating for a minute, they were dipped into 5 $\mathrm{L}$ of the chemical mixtures making sure they were fully submerged. The fruits were left in the mixture for $20 \mathrm{~min}$ to leave a thin film and then brought out to air dry. Untreated fruits served as control.

\section{Physico-Chemical Analysis}

Plantain fruits were analysed using the post-harvest screening methods developed by Ferris et al. (1999) to determine moisture content, total soluble solids (TSS), days to ripening and weight loss. TSS was determined with a digital refractometer (Atago PR-100, Tokyo, Japan) while days to ripening of fruits treated with chemicals were determined visually using the ripening colour scale described. Weight loss of fruits treated with chemicals was observed by measuring changes in fruit weight on a daily basis from harvest until the fruits reached colour stage nine. Titratable acidity was determined manually as described by Dadzie and Orchard (1997). Titratable acidity, moisture content and TSS were performed on the day of harvest.

\section{Modelling and Statistical Analysis}

This was carried out using Design Expert ${ }^{\mathrm{TM}}$ software version 7.0.3, Statease, Minneapolis, USA (Linforth et al., 2010). Response surface type of modelling, quadratic design model and historic data design were selected on the software. Data generated from the physicochemical analysis above were then imported into the software as historic data from Microsoft Excel ${ }^{\mathrm{TM}}$ files. Modelling terms were chosen by selecting, chemical concentration, plantain variety and chemical type as independent variables whereas days to ripening and weight loss were taken as dependent variables (responses). Analysis of variance was carried out on the model for each response at three stages of ripening (stages 3, 6, 9) to determine significant modelling terms and statistical significance was set at $(\mathrm{P} \leq 0.05)$. Model diagnostics were performed after which models with adequate precision were determined. According to the software instructions, the adequate precision parameter measures the signal to noise ratio and a ratio greater than 4 is desirable.

\section{Results and Discussion}

Titratable Acidity, Moisture Content and TSS of Plantain

The fruits used in this study were matured to the point that it was of acceptable eating quality visually (Dzomeku et al., 2016). The PITA 2 hybrid was chosen for this study 
because it is resistant to black sigatoka disease (Mobambo et al., 1993) while the local variety Agbagba was included because it is associated with very big fruit weight among several cultivars (Baiyeri and Tenkouano 2008). The fruits of the other local cultivar Obino l'Ewai are smaller than that of Agbagba and were chosen because it is one of the parents of the hybrid under study. Due to some restrictions at the study location, the actual planting date of the plants that yielded the fruits used was not disclosed. Hence some physico-chemical qualities of the fruits were determined on the day of harvest in order to establish the quality of the fruits used for this study.

Results (Table 1) showed that there were no significant differences $(\mathrm{P}>0.05)$ between the hybrid fruits and fruits of local plantain varieties which implies that the physico-chemical qualities of fruits tested are similar. The local variety Agbagba had higher titratable acid content (up to 20\%) than the hybrid fruits whereas the hybrid fruits had higher (up to 6\%) pulp moisture content and TSS than the two local cultivars. In agreement with a previous work, Ferris et al. (1999) found that tetraploid hybrid PITA 2 (TMPx 548-9) had higher TSS than the local cultivars Obino l'Ewai and Agbagba. Values of moisture content obtained were within range of other studies (Carvalho et al., 2009) and the general consensus by many investigators is that the degree of ripening or maturity may determine chemical composition (Emaga et al., 2007). In particular, harvest maturity is believed to affect chemical compounds abundance (El Hadi et al., 2013).

\section{Ripening and Weight Loss of Fruits Treated With Chemicals}

Chemicals used in this study were chosen because they are known among the most active organic acids used in food preservation (Davidson and Taylor, 2007). Also they are in the FDA (2017) GRAS database where it shows that acetic (ID code 64-19-7), sorbic (ID 110-44-1) and propionic (ID 79-09-4) acids are listed as GRAS chemicals. The results of ripening and weight loss of fruits treated with chemical preservatives are shown in Tables $2 \mathrm{a}-2 \mathrm{c}$. There was no dramatic extension of the preclimateric period (green life) or prevention of colonization of the fruits by post-harvest storage organisms after complete ripening or yellowing of the fruits. Also, no significant differences $(\mathrm{P}>0.05)$ were recorded for fruits of the local cultivars and hybrid fruits. Ripening progressed and took 2-3 weeks for fruits to reach ripening colour stage 9 when the fruits are black and show visible lesions of microbial colonization. The longest ripening days ( 24 days) to stage 9 was achieved with fruits of local cultivar Agbagba treated with 3\% propionic acid (Table 2c). Fruits of PITA 2 hybrid treated with propionic and sorbic acid at 3\% (Table 2c) showed the longest time (18 days) to complete yellowing of the fruits (ripening stage 6) which indicated that the chemicals may work better at higher concentrations.

The number of days until complete yellowing of untreated plantain fruits was within the range reported by Baiyeri and Tenkouano (2008). It is possible the chemical concentrations used were not enough to totally slow down the ripening process and inhibit microbial colonization of the fruits. According to Paniagua et al. (2014), textural changes during fruit ripening are mainly due to the dissolution of the middle lamella, the reduction of cell-tocell adhesion and the weakening of parenchyma cell walls as a result of the action of cell wall modifying enzymes. Also fruit deterioration during ripening is accompanied by weight loss which may be influenced by relative humidity (Kader, 2013). A suitable chemical preservative has been defined as one that can extend storage life of fresh fruits and reduce decay without affecting their quality (Dhall, 2013). For all chemical concentrations and plantain cultivars analysed, weight loss increased progressively from the day of harvest until colour stage 9. It was highest in the Obino l'Ewai local cultivar (Tables 2a-2c) for all chemical types and concentrations used. Weight loss in plantain has been reported by others (Sugri et al., 2010) and it causes faster ripening (Ferris et al., 1999) which may be due to increased respiration. According to Fonseca et al. (2002), respiration is the main process of deterioration of fresh produce and it is a metabolic process that ensures the oxidative breakdown of organic substrates into simple molecules. The oxidative breakdown in the Obino l'Ewai local cultivar may be worth exploring in order to gain more understanding on how to reduce weight loss.

\section{Modelling and Analysis of Variance}

In order to gain more insights from the ripening and weight loss data, modelling was carried out. This study was preliminary in nature and sample size was small hence less emphasis was laid on generation of model contour plots which may not give a good picture of data analysed. The Design Expert ${ }^{\mathrm{TM}}$ software modelling tool that was used in this study has been used in other studies (Khoshtinat et al., 2017). Overall, the modelling output (Table 3a-3c) showed adequate precision values of more than 4 in all cases which indicated a good noise to signal ratio. This suggests that there was little impact of postharvest handling and processing on the parameters measured.

Table 1 Physico-chemical qualities of plantain fruits used in this study

\begin{tabular}{l|ccc}
\hline \multicolumn{1}{c|}{ Cultivar } & Total soluble solids & Titratable acidity (\%) & Pulp Moisture (\%) \\
\hline Agbagba & $3 \pm 0.47$ & $1.8 \pm 0.08$ & $66.35 \pm 0.60$ \\
Obino l'Ewai & $4.67 \pm 0.46$ & $1.37 \pm 0.12$ & $67.86 \pm 0.78$ \\
PITA 2 & $5.57 \pm 0.47$ & $1.50 \pm 0.16$ & $70.46 \pm 1.01$ \\
\hline
\end{tabular}


Table 2a Average ripening at different ripening stage (RS) and weight loss (WL) of plantain fruits treated with $1 \%$ chemical concentration at different RS

\begin{tabular}{l|lcccccc}
\hline \multicolumn{1}{c|}{ Cultivar } & Chemical & $\begin{array}{c}\text { RS stage 3 } \\
\text { (days) }\end{array}$ & $\begin{array}{c}\text { RS stage 6 } \\
\text { (days) }\end{array}$ & $\begin{array}{c}\text { RS stage 9 } \\
\text { (days) }\end{array}$ & $\begin{array}{c}\text { WL stage 3 } \\
(\%)\end{array}$ & $\begin{array}{c}\text { WLstage 6 } \\
\%)\end{array}$ & $\begin{array}{c}\text { WL stage 9 } \\
(\%)\end{array}$ \\
\hline Agbagba & Acetic & $4 \pm 0.00$ & $10 \pm 0.43$ & $15 \pm 0.53$ & $5.70 \pm 1.51$ & $18.4 \pm 0.29$ & $22.21 \pm 0.63$ \\
Obino l'Ewai & Acetic & $4 \pm 0.00$ & $6 \pm 0.24$ & $13 \pm 0.32$ & $13.9 \pm 0.17$ & $15.32 \pm 0.71$ & $16.22 \pm 0.13$ \\
PITA 2 & Acetic & $4 \pm 0.00$ & $12 \pm 0.48$ & $21 \pm 0.41$ & $9.95 \pm 0.82$ & $13.94 \pm 0.49$ & $18.06 \pm 0.79$ \\
Agbagba & Propionic & $4 \pm 0.00$ & $10 \pm 0.41$ & $19 \pm 0.64$ & $4.85 \pm 0.16$ & $15.6 \pm 0.94$ & $19.33 \pm 0.74$ \\
Obino l'Ewai & Propionic & $4 \pm 0.00$ & $10 \pm 0.35$ & $17 \pm 0.52$ & $11.48 \pm 0.72$ & $20.21 \pm 0.84$ & $28.01 \pm 0.48$ \\
PITA 2 & Propionic & $5 \pm 0.00$ & $12 \pm 0.49$ & $18 \pm 0.61$ & $8.70 \pm 0.29$ & $20.38 \pm 0.76$ & $26.34 \pm 0.31$ \\
Agbagba & Sorbic & $4 \pm 0.00$ & $10 \pm 0.52$ & $19 \pm 0.16$ & $5.70 \pm 0.14$ & $15.52 \pm 0.71$ & $25.22 \pm 0.41$ \\
Obino l'Ewai & Sorbic & $4 \pm 0.00$ & $13 \pm 0.51$ & $18 \pm 0.47$ & $12.50 \pm 0.24$ & $22.56 \pm 0.26$ & $23.66 \pm 0.31$ \\
PITA 2 & Sorbic & $4 \pm 0.00$ & $12 \pm 0.64$ & $22 \pm 0.31$ & $16.17 \pm 0.35$ & $21.48 \pm 0.25$ & $24.25 \pm 0.35$ \\
Agbagba & Control & $4 \pm 0.00$ & $10 \pm 0.20$ & $14 \pm 0.41$ & $4.34 \pm 0.32$ & $15.19 \pm 0.37$ & $22.81 \pm 0.55$ \\
Obino 1'Ewai & Control & $4 \pm 0.00$ & $6 \pm 0.06$ & $12 \pm 0.60$ & $12.37 \pm 0.06$ & $12.38 \pm 0.18$ & $17.78 \pm 0.42$ \\
PITA 2 & Control & $5 \pm 0.00$ & $15 \pm 0.20$ & $19 \pm 0.41$ & $9.34 \pm 0.22$ & $17.23 \pm 0.18$ & $26.65 \pm 0.57$ \\
\hline
\end{tabular}

Table $2 \mathrm{~b}$ Average ripening at different ripening stage (RS) and weight loss (WL) of plantain fruits treated with $2 \%$ chemical concentration at different RS

\begin{tabular}{l|lcccccc}
\hline \multicolumn{1}{c}{ Cultivar } & Chemical & $\begin{array}{c}\text { RS stage 3 } \\
\text { (days) }\end{array}$ & $\begin{array}{c}\text { RS stage 6 } \\
(\text { days })\end{array}$ & $\begin{array}{c}\text { RS stage 9 } \\
(\text { days })\end{array}$ & $\begin{array}{c}\text { WL stage 3 } \\
(\%)\end{array}$ & $\begin{array}{c}\text { WL stage 6 } \\
(\%)\end{array}$ & $\begin{array}{c}\text { WL stage 9 } \\
(\%)\end{array}$ \\
\hline Agbagba & Acetic & $4 \pm 0.00$ & $10 \pm 0.68$ & $18 \pm 0.09$ & $6.49 \pm 0.10$ & $11.38 \pm 0.86$ & $23.11 \pm 0.56$ \\
Obino l'Ewai & Acetic & $4 \pm 0.00$ & $10 \pm 0.73$ & $17 \pm 0.94$ & $6.70 \pm 0.14$ & $15.63 \pm 0.77$ & $28.91 \pm 0.90$ \\
PITA 2 & Acetic & $4 \pm 0.00$ & $15 \pm 0.72$ & $19 \pm 0.05$ & $6.08 \pm 0.43$ & $18.81 \pm 0.30$ & $26.79 \pm 0.10$ \\
Agbagba & Propionic & $4 \pm 0.00$ & $10 \pm 0.72$ & $18 \pm 0.45$ & $4.14 \pm 0.07$ & $10.80 \pm 0.09$ & $19.67 \pm 0.01$ \\
Obino 1'Ewai & Propionic & $4 \pm 0.00$ & $10 \pm 0.94$ & $17 \pm 0.22$ & $6.74 \pm 0.59$ & $15.69 \pm 0.62$ & $23.54 \pm 0.73$ \\
PITA 2 & Propionic & $5 \pm 0.00$ & $14 \pm 0.47$ & $21 \pm 0.41$ & $9.76 \pm 0.22$ & $17.67 \pm 0.63$ & $22.07 \pm 0.44$ \\
Agbagba & Sorbic & $4 \pm 0.00$ & $10 \pm 0.41$ & $22 \pm 0.07$ & $4.14 \pm 0.35$ & $10.09 \pm 0.37$ & $21.30 \pm 0.11$ \\
Obino l'Ewai & Sorbic & $4 \pm 0.00$ & $11 \pm 0.49$ & $17 \pm 0.48$ & $7.31 \pm 0.04$ & $17.53 \pm 0.25$ & $31.11 \pm 0.08$ \\
PITA 2 & Sorbic & $4 \pm 0.00$ & $15 \pm 0.47$ & $21 \pm 0.94$ & $7.07 \pm 0.46$ & $22.43 \pm 0.06$ & $27.26 \pm 0.50$ \\
Agbagba & Control & $4 \pm 0.00$ & $9 \pm 0.74$ & $16 \pm 0.37$ & $7.48 \pm 0.25$ & $12.23 \pm 0.39$ & $27.8 \pm 0.31$ \\
Obino l'Ewai & Control & $4 \pm 0.00$ & $9 \pm 0.42$ & $17 \pm 0.23$ & $9.98 \pm 0.12$ & $16.65 \pm 0.31$ & $27.16 \pm 0.54$ \\
PITA 2 & Control & $4 \pm 0.00$ & $14 \pm 0.01$ & $17 \pm 0.21$ & $12.03 \pm 0.02$ & $19.63 \pm 0.32$ & $28.86 \pm 0.48$ \\
\hline
\end{tabular}

Table 2c Average ripening at different ripening stage (RS) and weight loss (WL) of plantain fruits treated with $3 \%$ chemical concentration at different RS.

\begin{tabular}{l|lcccccc}
\hline \multicolumn{1}{c|}{ Cultivar } & Chemical & $\begin{array}{c}\text { RS stage 3 } \\
\text { (days) }\end{array}$ & $\begin{array}{c}\text { RS stage 6 } \\
(\text { days })\end{array}$ & $\begin{array}{c}\text { RS stage 9 } \\
(\text { days })\end{array}$ & $\begin{array}{c}\text { WL stage 3 } \\
(\%)\end{array}$ & $\begin{array}{c}\text { WL stage 6 } \\
(\%)\end{array}$ & $\begin{array}{c}\text { WL stage 9 } \\
(\%)\end{array}$ \\
\hline Agbagba & Acetic & $4 \pm 0.00$ & $16 \pm 0.44$ & $22 \pm 0.61$ & $4.42 \pm 0.26$ & $16.22 \pm 0.37$ & $22.77 \pm 0.58$ \\
Obino l'Ewai & Acetic & $4 \pm 0.00$ & $12 \pm 0.11$ & $16 \pm 0.47$ & $11.4 \pm 0.28$ & $17.74 \pm 0.82$ & $23.50 \pm 0.71$ \\
PITA 2 & Acetic & $3 \pm 0.00$ & $13 \pm 0.50$ & $18 \pm 0.06$ & $8.46 \pm 0.41$ & $14.11 \pm 0.08$ & $20.47 \pm 0.35$ \\
Agbagba & Propionic & $6 \pm 0.00$ & $17 \pm 0.76$ & $24 \pm 0.10$ & $4.67 \pm 0.16$ & $15.12 \pm 0.22$ & $22.76 \pm 0.11$ \\
Obino l'Ewai & Propionic & $4 \pm 0.00$ & $12 \pm 0.09$ & $16 \pm 0.63$ & $12.36 \pm 0.30$ & $18.21 \pm 0.38$ & $22.52 \pm 0.25$ \\
PITA 2 & Propionic & $4 \pm 0.00$ & $18 \pm 0.43$ & $18 \pm 0.35$ & $7.87 \pm 0.41$ & $13.11 \pm 0.42$ & $20.11 \pm 0.89$ \\
Agbagba & Sorbic & $4 \pm 0.00$ & $16 \pm 0.48$ & $22 \pm 0.41$ & $5.82 \pm 0.08$ & $14.01 \pm 0.25$ & $25.32 \pm 0.27$ \\
Obino l'Ewai & Sorbic & $4 \pm 0.00$ & $13 \pm 0.41$ & $16 \pm 0.41$ & $8.22 \pm 0.37$ & $17.13 \pm 0.04$ & $25.67 \pm 0.15$ \\
PITA 2 & Sorbic & $4 \pm 0.00$ & $18 \pm 0.25$ & $22 \pm 0.26$ & $8.19 \pm 0.38$ & $18.02 \pm 0.10$ & $24.19 \pm 0.69$ \\
Agbagba & Control & $4 \pm 0.00$ & $15 \pm 0.20$ & $21 \pm 0.63$ & $4.74 \pm 0.11$ & $14.74 \pm 0.41$ & $25.36 \pm 0.37$ \\
Obino l'Ewai & Control & $4 \pm 0.00$ & $11 \pm 0.21$ & $15 \pm 0.26$ & $12.2 \pm 0.46$ & $18.71 \pm 0.34$ & $29.07 \pm 0.27$ \\
PITA 2 & Control & $4 \pm 0.00$ & $12 \pm 0.42$ & $16 \pm 0.08$ & $9.23 \pm 0.12$ & $13.22 \pm 0.37$ & $23.24 \pm 0.12$ \\
\hline
\end{tabular}

The precision was higher in ripening than weight loss in the green and yellow ripening stage (Table 3a-b) and no difference was found in the model precision value (Table 3c) when the fruits turned black (stage 9). This indicates that there was less variation in ripening and weight loss between local cultivars and hybrid fruits when the fruits turn black and are colonised by post-harvest spoilage organisms. It was found that days to ripening response model was significant $(\mathrm{P}<0.05)$ whereas weight loss was not $(\mathrm{P}>0.05)$ in all stages of ripening analysed which indicated that the chemicals may only affect surface activities of the fruit and not moisture loss. In agreement with the adequate precision values, the days to ripening parameter also showed stronger associations and less variation than weight loss based on the $\mathrm{R}^{2}$ and coefficient of variation (CV) values (Table 3a-3c). 
In Tables 3a-3c, the modelling performed showed the impact of chemical concentration (A), plantain variety (B) or chemical type $(\mathrm{C})$ or a combination $(\mathrm{AB}, \mathrm{AC}$ or $\mathrm{BC})$ on the ripening and weight loss process. This was consistent with the overall results, and there was no significant $(\mathrm{P}>0.05)$ impact of chemical concentration, plantain variety, chemical type (C) or a combination on weight loss of plantain fruits analysed. However these variables had an impact on ripening and it was highest for plantain variety $(\mathrm{P}<0.01)$ in all stages of ripening. In ripening stage 3 (Table 3a) where the fruits were more green than yellow, chemical concentration $(\mathrm{P}<0.05)$ had more impact than chemical type $(\mathrm{P}>0.05)$ whereas at stage 6 of ripening (Table $3 \mathrm{~b}$ ) where the fruit were more yellow than green it was vice versa. When the fruits turned more black than yellow due to microbial colonization (Table 3c), it was found that all the variables had an impact $(\mathrm{P}<0.05)$. This indicates that the chemicals preservatives studied may facilitate the reduction of fruit surface microbial colonization and it its effectiveness appears to increase as the fruit ripen.

Table 3a Analysis of variance table for days to ripening and weight loss from response surface quadratic model for plantain fruits treated with chemicals at stage 3 of ripening

\begin{tabular}{l|ccccc}
\hline \multicolumn{1}{c|}{ Source } & Sum of squares & df & Mean square & F- value & p-value \\
\hline Days to ripening & & & & & \\
Model & 54.15 & 20 & 7.71 & 11.45 & $\leq .0001$ \\
A & 3.38 & 1 & 3.38 & 5.89 & 0.0283 \\
B & 136.31 & 5 & 27.26 & 47.56 & $\leq .0001$ \\
C & 1.41 & 2 & 0.70 & 1.23 & 0.3208 \\
AB & 7.90 & 5 & 1.58 & 2.76 & 0.0583 \\
AC & 1.44 & 2 & 0.72 & 1.26 & 0.3120 \\
BC & 3.04 & 4 & 0.76 & 1.32 & 0.3059 \\
A & 1.12 & 1 & 1.12 & 1.96 & 0.1816 \\
\hline Weight loss & & & & 2.07 & 0.13 \\
Model & 368.80 & 20 & 18.44 & 6.41 & 0.7232 \\
A & 1.16 & 1 & 57.15 & 1.66 & 0.0522 \\
B & 285.75 & 5 & 14.84 & 0.52 & 0.2224 \\
C & 29.68 & 2 & 4.65 & 0.05 & 0.7562 \\
AB & 23.26 & 5 & 0.42 & 0.46 & 0.9546 \\
AC & 0.83 & 2 & 4.13 & 2.35 & 0.7617 \\
BC & 16.52 & 4 & 21.00 & 0.1457 \\
A & 21.00 & 1 & & & \\
\hline
\end{tabular}

$\mathrm{A}=$ Chemical concentration; $\mathrm{B}=$ Plantain variety $\mathrm{C}=$ Chemical type, Days to ripening model $-\mathrm{R}^{2}=0.95, \mathrm{CV}(\%)=13.98$, Adequate precision $=$ 11.91 , Weight loss model $-\mathrm{R}^{2}=0.73, \mathrm{CV}=33.84$, Adequate precision $=5.26$.

Table $3 \mathrm{~b}$ Analysis of variance table for days to ripening and weight loss from response surface quadratic model for plantain fruits treated with chemicals at stage 6 of ripening

\begin{tabular}{l|ccccc}
\hline \multicolumn{1}{c|}{ Source } & Sum of squares & $\mathrm{df}$ & Mean square & F- value & $\mathrm{p}$-value \\
\hline Days to ripening & & & & & \\
Model & 280.64 & 20 & 14.03 & 5.31 & 0.0009 \\
A & 13.50 & 1 & 13.50 & 5.11 & 0.0392 \\
B & 148.53 & 5 & 29.71 & 11.23 & 0.0001 \\
C & 24.67 & 2 & 12.33 & 4.66 & 0.0266 \\
AB & 63.17 & 5 & 12.63 & 4.78 & 0.0082 \\
AC & 10.11 & 2 & 5.06 & 1.91 & 0.1821 \\
BC & 9.78 & 4 & 2.44 & 0.92 & 0.4757 \\
A & 5.56 & 1 & 5.56 & 2.10 & 0.1678 \\
\hline Weight loss & & & & & \\
Model & 247.67 & 20 & 12.38 & 0.00 & 0.5093 \\
A & 7.32 & 1 & 19.32 & 1.54 & 0.4541 \\
B & 95.58 & 5 & 2.20 & 0.18 & 0.2355 \\
C & 4.40 & 2 & 6.33 & 0.51 & 0.8390 \\
AB & 31.67 & 5 & 12.68 & 1.02 & 0.7635 \\
AC & 25.36 & 2 & 13.41 & 1.08 & 0.3830 \\
BC & 53.63 & 4 & 9.45 & 0.76 & 0.4000 \\
A $^{2}$ & 9.45 & 1 & & 0.3960 \\
\hline
\end{tabular}

$\mathrm{A}=$ Chemical concentration; $\mathrm{B}=$ Plantain variety; $\mathrm{C}=$ Chemical type, Days to ripening model $-\mathrm{R}^{2}=0.88, \mathrm{CV}(\%)=13.40$, Adequate precision $=$ 9.48, Weight loss model $-\mathrm{R}^{2}=0.57, \mathrm{CV}=21.41$, Adequate precision $=4.56$. 
Table 3c Analysis of variance table for days to ripening and weight loss from response surface quadratic model for plantain fruits treated with chemicals at stage 9 of ripening

\begin{tabular}{l|ccccc}
\hline \multicolumn{1}{c|}{ Source } & Sum of squares & df & Mean square & F- value & p-value \\
\hline Days to ripening & & & & & \\
Model & 198.15 & 20 & 9.91 & 4.56 & 0.0022 \\
A & 1.04 & 1 & 1.04 & 0.48 & 0.4993 \\
B & 123.79 & 5 & 24.76 & 11.39 & 0.0001 \\
C & 22.89 & 2 & 11.44 & 5.27 & 0.0185 \\
AB & 32.57 & 5 & 6.51 & 3.00 & 0.4452 \\
AC & 3.44 & 2 & 1.72 & 0.79 & 0.4708 \\
BC & 5.11 & 4 & 1.28 & 0.59 & 0.6764 \\
A $^{2}$ & 1.13 & 1 & 1.13 & 0.52 & 0.4829 \\
\hline Weight loss & & & & & \\
Model & 353.74 & 20 & 17.69 & 1.60 & 0.1780 \\
A & 0.086 & 1 & 0.086 & 7.823 & 0.9307 \\
B & 127.68 & 5 & 25.54 & 2.31 & 0.0957 \\
C & 46.54 & 2 & 23.27 & 2.11 & 0.1562 \\
AB & 78.78 & 5 & 15.76 & 1.43 & 0.2711 \\
AC & 7.15 & 2 & 3.58 & 0.32 & 0.7284 \\
BC & 53.67 & 4 & 13.42 & 1.21 & 0.3456 \\
$\mathrm{~A}^{2}$ & 11.47 & 1 & 11.47 & 1.04 & 0.3243 \\
\hline
\end{tabular}

$\mathrm{A}=$ Chemical concentration; $\mathrm{B}=$ Plantain variety; $\mathrm{C}=$ Chemical type, Days to ripening model $-\mathrm{R}^{2}=0.85, \mathrm{CV}(\%)=7.86$, Adequate precision $=5.86$ Weight loss model $-\mathrm{R}^{2}=0.68, \mathrm{CV}=13.61$, Adequate precision $=5.86$

The fact that plantain variety was the most significant model term in all stages of ripening suggests that different plantain cultivars may need specific chemical treatment during ripening. It has been emphasised that understanding the basis of ripening would enable the expansion of plantain utilization (Baiyeri et al., 2011). Hence, further post-harvest work with increased chemical concentrations needs to be carried out and other hybrids and local cultivars should be analysed to determine if there is any effect specific to new hybrids or local landraces. The obvious advantage for these set of chemicals is that they are GRAS and may not affect the internal metabolism of the fruit.

\section{Conclusions}

After chemical treatment, it appears that the chemicals at higher concentrations may have an effect on ripening of the fruits and will need further investigation. Weight loss of fruits from the plantain hybrid and local cultivars were not affected by the chemical concentration, chemical type and plantain variety studied.

\section{Acknowledgement}

Authors acknowledge the support of International Institute of Tropical Agriculture, Nigeria.

\section{References}

Adegbola RO, Awosusi OO, Atiri GI, Kumar PL. 2013. First report of banana bunchy top virus in banana and plantain (Musa spp.) in Nigeria. Plant Dis. 97(2): 290.

Adeniji TA, Sanni LO, Barimalaa IS, Hart AD. 2007. Nutritional composition of five new Nigerian Musa hybrid cultivars: implications for adoption in human nutrition. Fruits, 62: 135-142.
Adeniyi OR, Ayandiji A. 2014. Economic analysis of post-harvest losses in plantain (and banana): a case study of south western Nigeria. Br. J. Appl. Sci. Technol., 4: 4456-4467.

Aked J, Wainwright H, Rees D, Westby A. 2000. A review of the postharvest research issues for cooking banana and plantain with specific reference to Ghana, Nigeria, Uganda and Tanzania. Acta Hortic. 540: 529-537.

Avallone S, Rojas-Gonzalez JA, Trystram G, Bohuon P. 2009. Thermal sensitivity of some plantain micronutrients during deep-fat frying. J. Food Sci. 74: C339-347.

Baiyeri KP, Tenkouano A. 2008. Fruit characteristics and ripening pattern of ten Musa genotypes in a sub-humid location in Nigeria. Fruits 63(1): 3-9.

Baiyeri K, Aba S, Otitoju G, Mbah O. 2011. The effects of ripening and cooking method on mineral and proximate composition of plantain (Musa sp. AAB cv.'Agbagba') fruit pulp. Afr. J. Biotechnol., 10: 6979-6984.

Carvalho GB, Silva DP, Santos JC, Izário-Filho HJ, Vicente AA, Teixeira JA, Felipe M, Almeida-Silva JB. 2009. Total soluble solids from banana: evaluation and optimization of extraction parameters. Appl. Biochem. Biotechnol., 153(1-3): 34-43.

Dadzie BK, Orchard JE. 1997. Routine post-harvest screening of banana/plantain hybrids: criteria and methods. INIBAP Technical Guidelines 2. Available: http://www.bioversity international.org/uploads/tx_news/Routine_post-harvest_ screening_of_banana_plantain_hybrids__Criteria_and_methods -235.pdf.

Davidson P, Taylor T. 2007. Chemical preservatives and natural antimicrobial compounds. In: Doyle, M., Beuchat, L. (eds), Food Microbiology: Fundamentals and Frontiers, Third Edition. ASM Press, Washington, DC. 713-745.

Dhall RK. 2013. Advances in edible coatings for fresh fruits and vegetables: a review. Crit. Rev. Food Sci. Nutr. 53: 435-550.

Dzomeku BM, Sarkordie-Addo J, Darkey SK, Bam RK, Wuensche J. 2016. Evaluating postharvest characteristics of Apantu (local false horn) plantain for harvest indices determination. Int. J. Plant Physiol. Biochem., 8(1): 1-6.

El Hadi MA, Zhang FJ, Wu FF, Zhou CH, Tao J. 2013. Advances in fruit aroma volatile research. Molecules, 18: 8200-8229. 
Emaga TH, Andrianaivo RH, Wathelet B, Tchango JT, Paquot M. 2007. Effects of the stage of maturation and varieties on the chemical composition of banana and plantain peels. Food Chem., 103: 590-600.

Famakin O, Fatoyinbo A, Ijarotimi OS, Badejo AA, Fagbemi TN. 2016. Assessment of nutritional quality, glycaemic index, antidiabetic and sensory properties of plantain (Musa paradisiaca)based functional dough meals. J. Food Sci. Technol., 53: 3865 3875 .

Faturoti BO, Ajayi AR, Baiyeri P, Madukwe MC. 2009. Impact of International Institute of Tropical Abriculture banana (Musa sp.) production technologies on small holder farmers in southern Nigeria. J. Appl. Sci., 9: 2592-2598.

FDA. 2017. United States Food and Drug Administration. Select Committee on GRAS Substances. Available online: http://www.accessdata.fda.gov/scripts/fdcc/?set=SCOGS\&sort= Sortsubstance $\&$ order $=$ ASC $\&$ startrow $=1 \&$ type $=$ basic $\&$ search $=p$ ropionic

Ferris RSB, Ortiz R, Vuylsteke D. 1999. Fruit quality evaluation of plantains, plantain hybrids, and cooking bananas. Postharvest Biol. Technol., 15: 73-81.

Fonseca SC, Oliveira FAR, Brecht JK. 2002. Modelling respiration rate of fresh fruits and vegetables for modified atmosphere packages: a review. J. Food Eng., 52(2): 99-119.

Kader AA. 2013. Postharvest technology of horticultural crops - An Overview from farm to fork. Ethiop.J. Appl. Sci. Technol., (Special Issue No.1): 1- 8 .

Khoshtinat K, Barzegar M, Sahari MA, Hamidi Z. 2017. Encapsulation of Iranian garlic oil with $\beta$-cyclodextrin: Optimization and its characterization. J. Agr. Sci. Tech., 19: 97 111.

Linforth R, Cabannes M, Hewson L, Yang N, Taylor A. 2010. Effect of fat content on flavor delivery during consumption: an in vivo model. J. Agric. Food Chem., 58: 6905-6911.

Mahajan PV, Caleb OJ, Singh Z, Watkins CB, Geyer M. 2014. Postharvest treatments of fresh produce. Philos. Trans. A Math Phys. Eng. Sci., 372(2017): 20130309. http://www.doi: 10.1098/rsta.2013.0309

Mobambo KN, Gauhl F, Vuylsteke D, Ortiz R, Pasberg-Gauhl C, Swennen R. 1993. Yield loss in plantain from black sigatoka leaf spot and field performance of resistant hybrids. Field Crops Res., 35(1): 35-42.

Moreira MR, Pereda M, Marcovich NE, Roura SI. 2011. Antimicrobial effectiveness of bioactive packaging materials from edible chitosan and casein polymers: assessment on carrot, cheese, and salami. J. Food Sci., 76(1): M54-63.
Norgrove L, Hauser S. 2014. Improving plantain (Musa spp. AAB) yields on small holder farms in West and Central Africa. Food Sec., 6: 501-514.

Nwaiwu O, Njoku HO, Efiuvwevwere BJO, Ortiz R, Tenkouano A. Ibekwe VI. 2003. Modified atmosphere packaging and biodeterioration of plantain. Int. J. Agric. Rural Dev. 4: 53-58.

Odenigbo MA, Asumugha VU, Ubbor S, Nwauzor C, Otuonye AC, Offia-Olua BI, Princewill-Ogbonna IL, Nzeagwu OC, HenryUneze HN, Anyika JU, Ukaegbu P, Umeh AS, Anozie GO. 2013. Proximate composition and consumption pattern of plantain and cooking-banana. Br. J. Appl. Sci. Technol. 3: 1035-1043.

Ogundare-Akanmu OA, Inana ME, Adindu MN. 2015. Preliminary quality evaluation of selected plantain flour (Musa paradisiaca) sold in Port Harcourt markets, Nigeria. Food Sci. Quality Mgt., 35: 7-10.

Orluchukwu JA, Ogburia MN. 2014. Introgression of $b s r$ gene from wild $2 \mathrm{n}$ accessions and derivative hybrids to cultivated $3 \mathrm{n}$ landraces of plantains (Musa Sp.) Int. J. Plant Res., 4(1): 1-4.

Ortiz R. 2013. Conventional banana and plantain breeding. Acta Hort. 986:177-194.

Ortiz R, Swennen R. 2014. From crossbreeding to biotechnologyfacilitated improvement of banana and plantain. Biotechnol. Adv. 32(1): 158-169.

Ortiz R, Vuylsteke D, Ferris RSB, Okoro JU, N'Guessan A, Hemeng OB, Yeboah DK, Afreh Nuamah K, Ahiekdor EKS, Agbor AN, Nwogu AN, Okoro E, Kayode G, Ipinoye I Y, Akele S, Lawrence A. 1997. Developing new plantain varieties for Africa. Plant Var. Seeds, 10: 39-57.

Paniagua C, Posé S, Morris VJ, Kirby AR, Quesada MA, Mercado JA. 2014. Fruit softening and pectin disassembly: an overview of nano structural pectin modifications assessed by atomic force microscopy. Ann. Bot., 114:1375-1383.

Sugri I, Norman JC, Egyir I, Johnson PNT. 2010. Preliminary assessment of shea butter waxing on the keeping and sensory qualities of four plantain (Musa AAB) varieties. Afr. J. Agric. Res., 5: 2676-2684.

Valencia-Chamorro SA, Palou L, Del Río MA, Pérez-Gago MB. 2011. Antimicrobial edible films and coatings for fresh and minimally processed fruits and vegetables: a review. Crit. Rev. Food Sci. Nutr., 51: 872-900.

Yurdugül S. 2016. Effects of edible coating - Semperfresh ${ }^{\mathrm{TM}}$, ascorbic acid and whey protein treatment on certain microbiological, physical and chemical qualities of peeled bananas “Musa sapientum”. Bulg. J. Agric. Sci., 22: 647-654. 